\title{
Valuing Geodiversity and Geoconservation: Developing a More Strategic Ecosystem Approach
}

\author{
JOHN E. GORDON* ${ }^{1} \&$ HUGH F. BARRON**
}

*Scottish Natural Heritage, Silvan House, 231 Corstorphine Road, Edinburgh EH 12 7AT, Scotland, UK and School of Geography and Geosciences, University of St Andrews, St Andrews, Fife KY16 9AL, Scotland, UK ${ }^{1}$

**British Geological Survey, Murchison House, West Mains Road, Edinburgh EH9 3LA, Scotland, UK

\begin{abstract}
This paper reviews the values and benefits of geodiversity and geoconservation in the context of Scotland's National Performance Framework and Strategic Objectives, particularly in relation to: economic development; climate change adaptation; biodiversity; science and education; and recreation, health and cultural inspiration. A key challenge is to improve the integration of geodiversity in environmental policy and in its implementation in order to deliver more holistic and sustainable environmental management and wider public benefits. This requires greater awareness and recognition of the key benefits and ecosystem services that geodiversity provides for society. With an overall objective of promoting integration of geodiversity into relevant policies and decision frameworks, we propose a more strategic, ecosystem-based approach to address: the future-proofing of ecosystem services, particularly in a context of climate change and rising sea-levels; conservation and sustainable management of geodiversity both in designated sites and in the wider countryside; raising awareness of the value of geodiversity and its contribution to ecosystem services; and improving understanding of geodiversity and key knowledge gaps. Such an approach is adopted in the Scotland's Geodiversity Charter.
\end{abstract}

KEY WORDS: Geodiversity, ecosystem approach, ecosystem services, strategic framework

What happens to us

Is irrelevant to the world's geology

But what happens to the world's geology

Is not irrelevant to us.

Hugh MacDiarmid, On a Raised Beach, 1933

\section{Introduction}

For its size, Scotland has a remarkable geodiversity, both on land and beneath Scottish territorial and offshore waters, reflecting a rich and varied geological history that spans some 3 billion years of the Earth's existence. This has stimulated the development of many of the fundamental principles that underlie geoscience today (Trewin, 2002; Gordon \& Barron, 2011). From a more applied viewpoint, Scotland's geodiversity has played, and continues to play, a critical role in national development, from providing coal, oil-shale and iron ore resources to power $19^{\text {th }}$ century industrialisation, to underpinning the development of new

${ }^{1}$ Present Address and Correspondence Address: John E. Gordon, School of Geography and Geosciences, University of St Andrews, St Andrews, Fife KY16 9AL, Scotland, UK. Email: jgordon0914@gmail.com 
technologies such as 'carbon capture and storage'. Geodiversity has thus contributed greatly to Scotland's financial wealth (Pye \& Brown, 2002; Rippon, 2002). Similarly, offshore, there are clear links between marine geodiversity and ecosystem support, healthy diverse seas and economic development (oil, gas and renewables) (Baxter et al., 2011). As presciently anticipated by Hugh MacDiarmid writing in the 1930s, geodiversity has much wider relevance in a number of key policy areas and forms the foundation of ecosystem services through its influence on landscape, habitats and species, economic activities, climate change adaptation, sustainable management of the land, river catchments and the coast, historical and cultural heritage, and people's health and well-being (Gordon \& Leys, 2001; Gray, 2004; Stanley, 2004; Stace \& Larwood, 2006; Gordon \& Barron, 2011). Many of these issues are being brought together under the UK Geodiversity Action Plan (UKGAP) ${ }^{1}$ and in advocacy for a more holistic approach that recognises the wider benefits of geodiversity to society and integrates geodiversity more closely in environmental policy (Prosser et al., 2011; Gordon et al., 2012).

At an international level, there is also growing awareness of the importance of the conservation of geodiversity ${ }^{2}$ and its wider values by the Council of Europe, the Nordic Council of Ministers, IUCN and UNESCO. The European Manifesto on Earth Heritage and Geodiversity (2004), advocates that unique Earth heritage sites and landscapes should be given protected status, and that sustainable development and restoration should respect and reflect geology, geomorphology and soils. In adopting Recommendation Rec(2004), the Committee of Ministers of the Council of Europe (2004) recognised the wider value of geodiversity: "geological heritage constitutes a natural heritage of scientific, cultural, aesthetic, landscape, economic and intrinsic values, which needs to be preserved and handed down to future generations". Noting "the important role of geological and geomorphological conservation in maintaining the character of many European landscapes”, the Committee also recommended that geological and geomorphological features are essential characteristics of landscapes that need to be considered when applying the European Landscape Convention (2002). Resolution 4.040 on 'Conservation of geodiversity and geological heritage', approved by the IUCN General Assembly (IUCN, 2008) at the 4th World Conservation Congress in Barcelona, provides a benchmark statement of the wider role and relevance of geodiversity. It acknowledges, inter alia:

- that geodiversity is an important natural factor underpinning biological, cultural and landscape diversity, as well as an important parameter to be considered in the assessment and management of natural areas;

- that geological heritage constitutes a natural heritage of scientific, cultural, aesthetic, landscape, economic and/or intrinsic values, which needs to be preserved and handed down to future generations;

- the escalating impact of development, that is frequently unsustainable, upon the world's geodiversity and geological heritage;

- that in planning such development, the intrinsic values, both material and intangible, of the geodiversity, geoheritage and geological processes present at natural areas are often underestimated or even ignored;

- that the conservation of geodiversity and geological heritage contributes to dealing with species loss and ecosystem integrity;

- the important role of geological and geomorphological conservation in maintaining the character of many landscapes. 
Through the Global Geoparks Network, UNESCO has promoted the cultural and economic importance of geodiversity as a means to deliver geoconservation as part of a wider strategy for regional sustainable socio-economic and cultural development that safeguards the environment (Eder \& Patzak, 2004). In Scandinavia, the Nordic Council of Ministers has supported collaborative geodiversity activities, including a report on Geodiversity in Nordic Nature Management (Johansson, 2000), that highlights geodiversity's wider values. In the Australian Natural Heritage Charter (Australian Heritage Commission, 2002), geodiversity is accorded equal status to biodiversity. There is therefore increasing acknowledgement, both in the UK and farther afield, that geodiversity has a vital relevance to society and that it impacts on many sectors in economic development and historical and cultural heritage through its contribution to ecosystem services. Crucially, the impacts on society and the costs of not understanding geodiversity have tended to be overlooked, with mismanagement resulting in soil erosion, landslides, enhanced impacts of flooding, coastal erosion and unsustainable use of resources. Although this is improving to some extent through natural flood management, catchment planning and integrated coastal zone management in many parts of the world, understanding of earth surface processes still needs to be integrated more comprehensively in policy, planning and decision frameworks (e.g. flooding in Thailand in 2011 had global economic implications due to unsuitable development on floodplains and lack of understanding of geomorphology ${ }^{3}$ ).

Nevertheless, geodiversity still lags significantly behind biodiversity in its recognition and integration in the wider policy environment, both in Scotland and more widely in the UK. In particular, there is a lack of a clear policy statement and national framework for geodiversity in Scotland, analogous to the Scottish Biodiversity Strategy, the Scottish Soil Framework or

| Scotland's Landscape Charter. The purpose of this paper is to-not to produce such a policy or strategy, but rather to outline the evidence base and supporting context. In particular, the aims are to: 1) review the wider values and benefits of geodiversity in the context of key environmental policy drivers, using an ecosystem services approach; 2) indicate how geodiversity supports wider policies and Scotland's National Performance Framework; and 3) identify the key areas that should be addressed as part of a more strategic approach to the conservation and management of geodiversity.

\section{The Values and Benefits of Geodiversity}

An ecosystem approach, as defined under the Convention on Biological Diversity ${ }^{4}$ seeks to achieve a more holistic way of looking after the natural environment and delivering more sustainable development. It recognizes that ecosystems are a form of public good, providing benefits and services that have value to people. The adoption of an ecosystem approach is now a key conservation policy driver, reflected in the Millennium Ecosystem Assessment (MA) (2005), the EU Biodiversity Strategy (European Commission, 2011), the UK National Ecosystem Assessment (2011) and the revised Scottish Biodiversity Strategy. Ecosystem services are typically grouped into four main categories as set out in the MA framework: provisioning, regulating and cultural services that directly affect people, and supporting services needed to maintain the other services. The significant role of geodiversity in contributing to ecosystem services is reviewed elsewhere (Gordon \& Barron, 2011; Gray, 2011, this volume). Here, we highlight 5 key areas that relate to Scotland's Strategic Objectives (Table 1): economic development; climate change adaptation; biodiversity; science and education; and recreation, health and cultural inspiration. 


\subsection{Economic development}

In Scotland, as in most countries, economic and industrial development during recent centuries has been founded on its geological resources. Today, these are fundamental to economic development and essential to maintaining our modern economy and lifestyle. A local supply of construction aggregates is vital for the building and maintenance of our infrastructure. Energy minerals including coal are used to generate a constant supply of electricity. In the UK, each person uses an average of over 10 tonnes of minerals and metals annually (British Geological Survey, 2008). Mineral resources are finite and they can only be worked where they occur. It is therefore essential that we use minerals in the most efficient and sustainable manner.

Scotland is fortunate to host significant useful mineral resources, which provide for local, regional, national and international needs. Resources include coal, igneous rock (for road surfacing), sand and gravel, limestone, sandstone, silica sand (mainly used for making glass containers), brick clay and peat (Hannis \& Bee, 2008; Bide et al., 2011). Half of Great Britain’s igneous rock comes from Scottish quarries, many of which produce important high specification aggregates. 33\% of the coal extracted in Britain comes from Scotland: nearly half of that from the surface mining sites in East Ayrshire (Bide et al., 2011). In 2009, the total value of minerals produced in Scotland (excluding oil and gas) was approximately $£ 610$ million. This represents $26 \%$ of the value of land-won minerals produced in the whole of the UK (Bide et al., 2011). The economy gains not only from the value of the indigenous mineral production itself, but also from the much greater value of the downstream industries that consume these raw materials, such as construction, energy production and chemicals manufacture, key sectors of both the Scottish and British economies. The construction industry is heavily dependent on locallysourced raw materials to reduce transport costs and maintain competitiveness. Construction aggregates represent half the value of all minerals produced in Scotland. Employment is also an economic indicator of the importance of minerals. Onshore mineral extraction (excluding coal) in Scotland provides around 1500 direct and over 4000 indirect jobs (Department for Communities and Local Government, 2011), many of which are in rural areas. Offshore, Oil and Gas UK estimate the workforce employed on the UK Continental Shelf at 350,000 (Bide et al., 2011).

Geodiversity also provides crucial resources for energy generation. Coal accounts for around $4028 \%$ of local and nationalScotland's electricity generation (Department for Energy and Climate Change, 2012). Oil and gas, too, have contributed significantly to the UK economy since the 1970s; in 2009, UK-produced oil and gas was valued at $£ 24.8 \mathrm{Bn}$ (at 2006 prices) (Bide et al., 2011). Onshore, UK-produced coal was valued at £906M (at 2006 prices) in 2009, with $35 \%$ of this produced in Scotland (Bide et al., 2011). During the post-war expansion of hydroelectric power in Scotland, many glens were dammed to provide a head of water to drive generating stations. More recently, the development of renewables has become one of the Scottish Government's highest priorities, with a target of generating the equivalent of $100 \%$ of electricity in Scotland from renewable sources by 2020. Onshore wind farms depend on suitable topographic locations, while the coastal and submarine topography facilitate development of tidal schemes and offshore wind farms. The tidal rapids within the Pentland Firth alone are expected to generate 1.2GW through wave and tidal devices. Many opportunities also exist for small-scale run-of-river hydro-electric schemes due to the nature of the terrain (elevation drop) and natural flow, providing that appropriate protection for the water environment and fisheries can be secured (SEPA, 2010; Robson et al., 2011).

Most of Scotland's famous landscapes and scenery are founded on geodiversity. Visitors to Scotland rank scenery as the main attraction of Scotland as a tourist destination, ahead of

Comment [MSOfficel]: For nongeologists, an explanation of the uses of igneous rock and silica sand would be useful

Comment [MSOffice2]: Much igneous rock is used close to source.

Comment [MSOffice3]: What has been the effect of in-quarry processing? I know Trearne is now back in the supply of agricultural lime with an in quarry plant.

or the UK?
or

Comment [MSOffice5]: Worth noting that most effective onshore windfarm is on Shetland. However, the remote location of many renewables sites is committing Scotland to a long-distance power transmission grid. This is not an easy system to incorporate local power generation into.

Comment [MSOffice6]: I know Penicuik Development Trust is investigating this. RoR schemes have been popular in the US and are often community-owned. Are there conflicts with salmonid fishing?

Formatted: Font: Italic 
history and culture (VisitScotland \& Scottish Natural Heritage, 2002). The country’s economy benefits by $£ 17.2$ billion a year from sustainable use of the natural environment (RPA \& Cambridge Econometrics, 2008). The environment also supports 242,000 jobs, or $14 \%$ of all full-time jobs in Scotland (RPA \& Cambridge Econometrics, 2008). However, the Scottish environment is much more than an asset for tourism-based activities. It provides an attractive environment in which to live and do business. For example, $20 \%$ of our industries depend to a large extent on the environment, including not only tourism, agriculture, fishing and forestry, but also food and drink production, water supplies, renewable energy, timber processing and recreation (RPA \& Cambridge Econometrics, 2008). Geodiversity is clearly a contributing factor in all these areas.

Geotourism is growing in importance, both globally and in Scotland, as reflected in the expansion of numbers of European and Global Geoparks ${ }^{5}$ and in the development of visitor attractions and products (McKeever et al., 2006; Dowling \& Newsome, 2010; Newsome \& Dowling, 2010). Geoparks provide a framework that supports sustainable economic development particularly in remote areas, geoconservation and opportunities for local communities to use the resource of their landscapes and their geological stories in creative ways for the development of geotourism-based activities and niche branding of local products and services (Eder \& Patzak, 2004; Hambrey Consulting, 2007; Morrison \& MacPhail, 2009). In Scotland, there are opportunities to develop more holistic interpretation linking geodiversity, biodiversity, land use, environmental resources and cultural heritage, using national gateways both real (e.g. Our Dynamic Earth and the museums) and virtual (e.g. the

| scottishgeology.com /website - http://www.scottishgeology.com/) linked to a network of regional hubs each with its own satellite sites (McKirdy et al., 2001). Where appropriate, such interpretation should integrate with existing visitor facilities and the National Parks and Geoparks, adding quality and value to the visitor experience. However, there are still major challenges for Scotland's Geoparks to engage with the business community and to develop a secure, long-term, financial model. Integration with the tourism industry at a strategic level

| will also be crucial, as indicated by the success of the 'Landscapes from Stone' programme in Ireland (McKeever \& Gallagher, 2001).

\subsection{Living in a dynamic world: adapting to climate change}

Understanding geodiversity, and particularly the responses of geomorphological processes, has a key part to play in adapting to climate change and sea-level rise. Changes in geomorphological processes are likely to have significant implications for most ecosystems. Some habitats may become more dynamic as a result of changes in the nature and rate of geomorphological processes. Enhanced or more variable rates of geomorphological activity may be too fast fornot allow some habitats and species to adapt. Increased incidence of flooding, and consequent enhanced erosion and rates of sediment movement, will affect the quality of freshwater and brackish habitats. Similarly, any changes in seasonal flows (e.g. in the timing and duration of droughts) will have implications for these habitats. Overall, there may also be less recovery time between extreme events, such as wash-out of spawning areas.

Climate change scenarios suggest that some landforming processes that are also hazardous (such as coastal flooding and erosion, flash floods and landslides) are likely to occur more frequently, and their effects may be exacerbated by the legacy of longer-term trends. For example, the postglacial uplift of Scotland is now being outpaced by global sea-level rise (Rennie \& Hansom, 2011). If the observed recent patterns are maintained, this has significant implications for the natural heritage, strategic planning, flood risk management and

Comment [MSOffice7]: I think this site is under redevelopment

Comment [MSOffice8]: Having visited the English Rivera geopark in December (Torquay area Devon, I was struck at the support from the council (Unitary Authority) and Kent's Cavern (local business with strong geodiversity link). Their reasoning was that by targetting outdoors-orientated visitors, they could extend their tourist season. Contrast this with Scotland. Lochaber which is pushing Fort William as the UK outdoors capital, has let the Geopark go. Strong similarities but different outcomes. Why? I would argue proximity and awareness of the Jurassic Coast in the case of Devon. In Lochaber, the sealochs and mountains seem to be treated as 'externalities'.

Comment [MSOffice9]: volatile or variable would better convey rapid switching in regimes. 
sustainable development on Scotland's coast, and particularly on low-lying coastal zones and river mouths around the major cities. The response to hazards often results in expensive siteby-site geotechnical solutions (e.g. more coast protection). Many of these approaches are not sustainable, and may exacerbate or transfer the problem elsewhere in the catchment or along the coast, with consequent impacts on natural heritage interests (e.g. reduced sediment supply to maintain beaches, machair and saltmarshes). For dynamic landscapes (rivers, coasts and steep hillsides), sustainable adaptation measures require, where practicable, allowing space for natural processes to operate, and minimising interventions that work against natural processes (Prosser et al., 2010). For example, landforms and habitats, such as beaches and salt marshes, act as natural forms of coast defence but require a sediment supply to maintain them and sufficient space to evolve (e.g. through managed realignment). To be effective, management decisions also need to be made at appropriate spatial scales (e.g. catchments and coastal zones). This is being recognized in the development of 'natural flood management', involving integrated catchment solutions and the restoration of the natural function of floodplains as flood buffers, with concomitant benefits for the natural heritage (e.g. under the Flood Risk Management (Scotland) Act 2009). The concepts of working with nature and making space for natural processes have broader value to society as a whole, not only in practical terms of managing flooding and coastal erosion, but also in terms of the economic costs of ignoring them. However, engagement of geoscientists with appropriate conservation agencies, land owners, communities and other stakeholders will be crucial (Prosser et al., 2010; Lane et al., 2011).

\subsection{Underpinning biodiversity}

Geodiversity is the foundation of all terrestrial ecosystems, delivering many essential supporting services for biodiversity, including soil formation, biogeochemical (nutrient) cycling and water cycling, as well as provision of minerals, nutrients, landform mosaics and geomorphological processes (e.g. water flow regimes) for habitat creation and maintenance. Scotland's biodiversity depends on the continued operation of these services. Many habitats owe their origins to geological and geomorphological processes (e.g. coastal sand dune/machair systems, the estuaries and salt marshes which provide the wintering sites for internationally important goose populations, and limestone pavements). Management of sites for biodiversity therefore requires an understanding of their geological and geomorphological setting and current process dynamics, for example in the management of freshwater (Corenblit et al., 2007; Vaughan et al., 2009), coastal (Everard et al., 2010; Jones et al., 2011) and upland (Thompson et al., 2001; Orr et al., 2008) systems. In many cases, maintaining natural processes is a key part of conserving biodiversity. Consequently, it is increasingly recognised that conservation management of the non-living parts of the natural world is crucial for sustaining living species and habitats (Hopkins et al., 2007; Beier \& Brost, 2010; Anderson $\&$ Ferree, 2010). The value of a more integrated approach for sustaining natural capital is now acknowledged at a strategic level, for example in the Convention on Biological Diversity and the European Landscape Convention and in the growing emphasis on an 'ecosystem approach' in conservation management. At a more practical level, it is being implemented through Integrated Coastal Zone Management and Integrated Catchment Management/Sustainable Flood Management schemes.

From a natural heritage viewpoint, more integrated approaches to nature conservation and the management of sites and landscapes would help to strengthen and add value to the Scottish Biodiversity Strategy (Scottish Executive, 2004) by recognising: i) the value of geodiversity as an intrinsic constituent of the natural heritage alongside biodiversity and landscape 
character; and ii) the role of geodiversity in supporting and regulating a wide range of environmental and ecological services essential for supporting habitats and species. In terms of management, it means conserving geodiversity and making space for natural processes as a form of insurance to help provide mosaics of environments (sites with the diverse geology, landforms, soils, drainage, water/sediment /nutrient flows) and options to enable habitats/species to be maintained, adapt, relocate or be restored and, where appropriate, supporting ecological networks and connectivity. Where practical, it also requires working with, rather than against, natural processes, in effect 'allowing space for nature' to enable coasts, floodplains and slopes to evolve with minimal human intervention, rather than attempting to 'fix and control'. This means accepting the inevitability of natural change as part of maintaining ecosystem functions, and in many cases attempting to maintain the status quo will not be an option (e.g. Pressey et al., 2007). In addition, learning from the past through analysis of palaeoenvironmental archives and geomorphological records can provide long-term perspectives on trends, rates of change and future trajectories in ecosystems (Dearing et al., 2010), which will help to inform adaptation, spatial analysis and scenario modelling of geomorphological risks to habitats, species and ecosystems, and assessment of how realistic biodiversity targets are, taking account of geodiversity factors and the magnitude and speed of their changes. Geodiversity-informed management strategies will therefore be a vital part of future-proofing biodiversity and ecosystems where that is practically possible, but their implementation will require close partnership working across the geoconservation and geoscience communities, as well as with other sectors of nature conservation, policy makers, planners and communities. It is vital that geologists and geomorphologists actively engage in wider networks and with those involved in conservation, ecosystem services and climate change adaptation work (e.g. through the Valuing Nature Network, the Living with Environmental Change programme and local initiatives) (Gray et al., submitted).

\subsection{Science and education}

Scotland's geodiversity has significant value as part of the geoheritage of Great Britain. The geological development of Scotland has given rise to an exceptional geodiversity, both on land and beneath Scottish territorial and offshore waters (Trewin, 2002; Gordon, 2010; Brooks et al., 2011). Many sites in Scotland are of great importance to geoscience for their rocks, fossils and landforms, demonstrating geological processes or events of international significance. This intrinsic value is encapsulated in the inclusion of key features of geological and geomorphological interest in the national system of Sites of Special Scientific Interest, based on the Great Britain wide Geological Conservation Review (GCR) (Ellis, 2011). Scotland's geodiversity is consequently an asset of national and international importance for geoscience research and education.

Scotland's geology and geologists have also played a fundamental part in the development of | the principal concepts in geoscience (including physical geography) (Gordon \& Barron, 2011). In particular, they have provided crucial evidence for interpreting geological events and processes of global significance associated with recognition of the duration of geological time, plate movements, crustal deformation, volcanism and ice ages. For example, evidence for the closure of the Iapetus Ocean and the formation of the Caledonian mountains, volcanism, events associated with the opening of the North Atlantic Ocean, and glaciation have all been instrumental in achieving fundamental advances in geoscience. Similarly, Scotland's fossil heritage has had an influential role in the development of the standard units of time and in advancing our understanding of the evolution of the plant and animal kingdoms. In the marine environment, the seabed beneath Scottish territorial and offshore

Comment [MSOffice11]: But so few biodiversity and conservation organizations have people with this knowledge in their teams. SNH is not replacing staff in this area. Much baseline information could be supplied from desktop work but the need for 'boots on the ground' remains. Who will fill this role? Ecological consultants, geotechnical firms?

Comment [MSOffice12]: on the basis of geological or geomorphological interest 
waters includes remarkably well preserved landforms that have revealed patterns and processes of ice stream behaviour within the last British-Irish Ice Sheet (Bradwell et al., 2008; Stoker et al., 2009), large submarine mass movement features (submarine slides), a range of dynamic bedforms (including sand and gravel waves and gas seepage forms) and areas of carbonate production that underpin onshore features such as the dunes and machair of the Western Isles and Northern Isles of Orkney (Brooks et al., 2011). Scotland's geodiversity is also significant in the context of our scientific and cultural heritage. The birth of modern geology took place in Scotland over 200 years ago through the discoveries of James Hutton, a leading figure in the Scottish Enlightenment, which laid the foundations of modern geoscience (McIntyre \& McKirdy, 2012). There is thus a long-established tradition of world-class scholarship in geoscience in Scotland which continues to the present day,

| prompted not least by ready access to-the extraordinary wealth of Scotland's geodiversity.

In its strategic framework for science in Scotland, Science for Scotland, the Scottish Government envisages science as key to delivering its Strategic Objectives and increasing sustainable economic growth (Scottish Government, 2008a). Geoscience is well-placed to meet these objectives in several high-level areas of particular relevance to society today ${ }^{6}$ :

- understanding of Earth and environmental sensitivity from the records of the past to enable testing of trajectories, scenarios and adaptation for the future;

- development of holistic Earth models for climate change, incorporating processes and feedbacks in the atmosphere, oceans and cryosphere;

- resource security and waste management;

- hazards - understanding risk and uncertainty in the Earth (including those of tectonic and volcanic origin but also related to the consequences of climate change, including sealevel rise).

Addressing these issues requires not only fundamental research, but also high quality training for future generations of geoscientists. This extends more widely both to schools and wider public awareness of geoscience through lifelong learning opportunities. The Scottish Earth Science Education Forum (SESEF) has been instrumental in integrating geoscience and its wider relevance across a number of key areas of the Curriculum for Excellence. An essential component of such training and education is the availability of sites for field study, which links directly to the need for effective geoconservation.

\subsection{Recreation, health and cultural inspiration}

Scotland's geodiversity provides many opportunities for outdoor recreation, ranging from walking and cycling to rock climbing, caving, skiing, orienteering, canoeing, sailing, camping and outdoor adventure. In doing so, it contributes to people's physical and mental health and well-being and to the Scottish Government's strategy on health and the environment (Scottish Government, 2008b). Regular exercise in the form of walking is an excellent way to improve health and to explore geology and landscape (Stinton, 2009). There are many opportunities for walking on existing geotrails (e.g. British Geological Survey, 2004; Scottish Natural Heritage, 2004) and through visits to GCR sites, Local Geodiversity sites $^{7}$ and Geoparks ${ }^{8}$. There is also significant potential for integrating geology into existing long- and short-distance trails and adding value to the many walking festivals taking place annually in Scotland. Guided walks in Scotland's Geoparks and during Scottish Geology Festival events add to people's enjoyment of the outdoors. The extension of the International 
Appalachian Trail to Scotland ${ }^{9}$ and other European countries will help to promote Scotland as a walking destination based on its geological heritage and landscapes. Use of new technologies such as iGeology (http://www.bgs.ac.uk/igeology/), mySoil (http://www.bgs.ac.uk/mysoil/) and interactive games (e.g. Rock Operator http://www.hoda.org.uk/hoda/Rock_operatoR.html) will also enhance the visitor experience and the engagement of young people.

There are also new opportunities to integrate geodiversity within the Central Scotland Green Network $(\mathrm{CSGN})^{10}$ that forms part of the Scottish Government's Second National Planning Framework published in July $2009^{11}$. This is one of 14 National Developments considered to be essential elements of the strategy for Scotland's long-term development. The CSGN aims to build on the work of a number of existing regional and local initiatives to improve the environmental quality in an area stretching from Ayrshire and Inverclyde in the west to East Lothian and Fife in the east. This will make the post-industrial landscape a more attractive place in which to live, visit and do business. It reflects a growing recognition by Government, public agencies and local authorities of the contribution that high-quality greenspace can make to a range of outcomes - from supporting sustainable economic growth and improving quality of life, to protecting biodiversity and helping Scotland mitigate and adapt to climate change. Local Geodiversity Sites and activities undertaken by local geodiversity groups have an important part to play in this process. In addition, there are opportunities to promote BTCV (formerly British Trust for Conservation Volunteers) Green Gym volunteering both for people's fitness and improvement of geodiversity assets by site works such as path making and enhancement of GCR sites and Local Geodiversity Sites.

Landscapes and their geological features have also exerted a strong creative influence expressed through literature and poetry in Scotland, notably in the novels of Sir Walter Scott, Robert Louis Stevenson, Lewis Grassic Gibbon, George Mackay Brown, Neil Gunn and others and in the poetry of Norman MacCaig, Sorley MacLean, Hugh MacDiarmid and Kenneth White, for example (Gordon, this volume). In landscape art, a radical change in perception of wild landscapes in the late $18^{\text {th }}$ and early $19^{\text {th }}$ centuries, from inhospitable places to be avoided, to awe-inspiring places to be experienced, was encouraged by the romantic Scottish painters such as John Knox, Horatio McCulloch, Alexander Nasmyth, and the English painters, Edwin Landseer and J.M.W. Turner (Holloway \& Errington, 1978). The creative influence of geodiversity is also continued in more modern landscape art and land art (Gordon, 2012; this volume). The popularising of interest in wild landscapes and natural features through literature and art helped to foster the early development of tourism in Scotland in the late $18^{\text {th }}$ and $19^{\text {th }}$ centuries (Hose, 2010; Gordon, 2012).

Geodiversity also contributes significantly to landscape character, in both rural and urban settings, and geoconservation plays an important part in maintaining the character of many of Scotland's iconic landscapes. This includes the built environment where the use of local or traditional stone and other geological materials (e.g. in vernacular buildings or stone walls) can contribute to the cultural heritage of an area. In recent decades there has been increased interest in indigenous stone, partly through a growing awareness of the importance of issues such as 'sense of place' and 'local distinctiveness', but also an increasing appreciation of natural stone as a modern architectural material. This has been reflected in a resurgence in the building stone industry in parts of Scotland, and a growing awareness of the importance of stone to the nation's cultural identity (Wilson, 2005; Hyslop et al., 2006). 


\section{Pressures on geodiversity}

It is a common misconception that geological features and landforms are sufficiently robust not to require active management or action planning (Mace et al., 2011). The pressures and threats facing geodiversity occur principally from development activities and land-use changes at both site and wider landscape scales (Werritty \& Brazier, 1991; Werritty et al., 1994; Lees et al., 1998; McKirdy, 2002; Gordon \& Barron, 2011). For example, these may arise through economic forces that determine the demand for minerals and changes in agri/forestry support measures that affect land use decisions. These may damage key features, impair their visibility and accessibility, fragment the interest and relationships between features and interrupt natural processes (Gordon \& Barron, 2011). The vulnerabilities of different types of site, and required conservation measures, are considered by Prosser et al. (2006). Wider off-site impacts may also occur; for example, erosion downdrift of coastal defences (Lees et al., 1998). Other impacts may arise from the effects of global processes (e.g. climate change and sea-level rise) (e.g. Gordon et al., 1998; Pethick, 1999; Prosser et al., 2010). These can act directly through enhanced erosion of coastal or riverbank exposures, or indirectly through demands for coastal protection or river management.

Sites located on the coast, adjacent to rivers or on active slopes are most likely to be impacted by climate change, sea-level rise and increased erosion or flooding. The human responses to these changes, in the form of 'hard' coastal protection or river and slope engineering are, however, likely to have a greater impact on geodiversity than direct climate changes alone (Prosser et al., 2010). Climate change presents particular management challenges that will require working with governments, planners, decision makers and local communities to ensure that geodiversity interests are managed sustainably as part of wider, long-term adaptation strategies (Prosser et al., 2010).

Human activities and development in the marine environment have the potential to impact upon both geomorphological and geological features at the seabed (Brooks et al., 2009; Defra, 2010). They include: fishing (dredge and trawling), aggregate extraction, hydrocarbons (oil and gas installations), renewable energy installations, cables and pipelines, navigational dredging, dredge waste disposal and military activity. Given the dynamic nature of the marine environment, all of these activities have the ability to cause near and far-field effects through the interruption of existing sediment transport pathways and hydrodynamic processes. Furthermore, any disturbance of soft sediments on the seabed will also give rise to the suspension of fine particles in the water column, potentially altering local-regional sedimentation patterns. The planned nearshore expansion of large windfarms is a relatively new pressure, with uncertain impacts on marine geomorphological processes.

\section{Policy context and the need for a strategic approach to geodiversity and geoconservation}

Geodiversity is an integral part of nature and has a fundamental bearing on the wealth, health and wellbeing of Scotland's people. It either supports or helps to deliver the Scottish Government's Strategic Objectives in various ways, which serves to demonstrate the important role that it can play in future sustainable development through its contribution to key policy areas, including the economy (employment and products), environment (nature conservation, flood protection, marine planning, global processes), health (recreational resource, artistic inspiration) and education (scientific discovery and evolutionary processes) (Table 1). However, a review of the links between geodiversity and the current policy framework 
identified a clear lack of integration of geodiversity despite its evident wide relevance (Natural Capital, 2011). A strategic framework or charter, similar to the Scottish Biodiversity Strategy, the Scottish Soil Framework or Scotland's Landscape Charter, would provide a means to highlight the wider role and benefits of geodiversity and associated geoconservation activities and to facilitate better integration into the policy framework as individual policies are revised or updated (e.g. within the Scottish Planning Policy (the consolidated SPP), the Scottish Biodiversity Strategy, landscape policy, greenspace strategy and cultural heritage | policy) ${ }^{12}$. It would help to identify strategic priorities for geoconservation activities and provide a framework for actions by different stakeholders and sectors, including local authorities, public agencies and government departments; land managers; developers; industry and business; and individuals, communities and non-governmental organisations. Importantly, it should align with, and support, the Scottish Government's National Outcomes and Strategic Objectives (Tables 1 and 2). In particular, it should recognise the value of geodiversity for its:

- contribution to sustainable economic development;

- role in sustainable (integrated) management of land and water at a landscape/ecosystem scale, including management and adaptation to climate change and sea-level rise;

- role in supporting Scotland's habitats and species, and providing ecosystem/environmental services;

- intrinsic interest as part of Scotland's natural heritage;

- contribution to Scotland's valued landscapes and cultural heritage;

- contribution to education/public health/quality of life/national well-being.

Such a framework should instigate a process through which key stakeholders would work together to achieve better public awareness of geodiversity, its protection and better integration in policy and guidance to deliver sustainable management of land and water, consistent with the economic, social, cultural and environmental needs of Scotland. The key objective should be integration through a more holistic, ecosystem-based approach, rather than adding stand-alone blanket provisions for conservation of geodiversity or simply 'bolting-on' geodiversity. With an overall objective of promoting integration of geodiversity into relevant policies, the priority areas of activity are:

- 'future-proofing' ecosystem services, particularly in a context of climate change and rising sea-levels, through the implementation of more integrated approaches in the sustainable management of the natural heritage, land and water at a landscape/ecosystem scale for the wider benefit of Scotland's people, environment and economy;

- conservation and sustainable management of Scotland's geodiversity, both in designated sites and in the wider countryside and beneath our seas, to maintain and enhance its special character and qualities and the benefits it provides;

- raising awareness of the values of geodiversity and ecosystem services and the wider links with landscape, culture and sense of place, and encouraging a sense of pride through appropriate interpretation, promotional and educational activities, and public enjoyment and involvement;

- improving understanding of geodiversity and vital knowledge gaps, including the key area of the functional linkages between geodiversity and biodiversity. 
The outcomes from these activities are identified in Table 2. Such a framework, Scotland's Geodiversity Charter, has now been developed by the Scottish Geodiversity Forum in partnership with a range of stakeholders (Scottish Geodiversity Forum, 2012, Miller, this volume).

\section{Conclusion}

In addition to its intrinsic scientific and educational values, Scotland's geodiversity is an integral part of the wider diversity in nature that delivers economic, social and environmental services and benefits for society. However, it remains a major challenge to develop and implement a more holistic approach to geodiversity, biodiversity and landscape conservation management that recognises the benefits to society of protecting and enhancing ecosystems and working with natural processes at a time of likely unprecedented changes in the natural world as a result of climate change and sea-level rise. Geodiversity makes an essential contribution to these services and geoconservation-related activities are directly linked to delivering the Scottish Government's National Outcomes and Strategic Objectives. These links show the value of a more holistic, ecosystem approach and how geodiversity can add value. However, the absence of references to geodiversity in high-level policy documents and in development planning policies highlights the need for implementation of a more strategic approach to geodiversity. Such an approach is adopted in Scotland's Geodiversity Charter should identifywhich identifies priorities and outlines a framework for action by stakeholders and relevant sectors. It should help to: 1) provide an environment in which the rich geodiversity of Scotland can be understood, valued and managed sustainably; and 2) make geodiversity relevant to the way we work and live, providing a sense of place and contributing to the decisions we make about a sustainable future for our environment, for both people and nature. Instigating an incremental process through which key stakeholders

| activities and better integration of geodiversity in relevant policy and guidance should help to deliver sustainable management of land and water, consistent with the economic, social, cultural and environmental needs of Scotland. Promoting wider awareness, understanding and involvement will be a crucial part of the process. At policy, planning and decision-making levels, understanding of the way the Earth works should be one of the cornerstones of sustainable development.

\section{Acknowledgements}

| We thank Clive Mitchell and Alistair McGowan for helpful comments on the manuscript and Robina Barton for improvements to Table 1. HFB publishes with permission of the Executive Director of the British Geological Survey.

\footnotetext{
Notes

${ }^{1}$ See http://www.ukgap.org.uk/ [Accessed on 25 January, 2012].

${ }^{2}$ Geodiversity is the variety of rocks, minerals, fossils, landforms sediments and soils, together with the natural processes which form and alter them. Geoconservation is "action taken with the intent of conserving and enhancing geological and geomorphological features, processes, sites and specimens” (Burek \& Prosser, 2008, p. 2).

${ }^{3}$ See ‘Floods sink Thais’ global factory’, Sunday Times Business Section, 6 November, 2011.
} 


\footnotetext{
${ }^{4}$ An ecosystem approach is defined under the Convention on Biological Diversity as “.... a strategy for the integrated management of land, water and living resources that promotes conservation and sustainable use in an equitable way.” http://www.cbd.int/ecosystem/ [Accessed on 25 January, 2012].

${ }^{5}$ See http://www.europeangeoparks.org/isite/page/52,1,0.asp?mu=4\&cmu=30\&thID=0 and http://www.globalgeopark.org/english/ [Accessed on 25 January, 2012].

${ }^{6}$ See reports of Workshops on 'Earth Sciences in the $21^{\text {st }}$ Century'

(http://www.bgs.ac.uk/ukgeoscience/home.html) and 'Earth Sciences in the 21st Century: a Scottish Perspective' (http://www.abdn.ac.uk/geology/events/events/c21scotland.php), held in January and February 2010 and co-ordinated by the Geological Society of London, the British Geological Survey and the Natural Environment Research Council. [Accessed on 25 January, 2012].

${ }^{7}$ For example, see the leaflets produced by Scottish Local Geodiversity Groups http://www.scottishgeology.com/findoutmore/rigs in scotland/L\&Binterpretive lflts.html [Accessed on 25 January, 2012].

${ }^{8}$ For example, see the websites of North West Highlands Geopark (http://www.northwest-highlandsgeopark.org.uk/), Lochaber Geopark (http://www.lochabergeopark.org.uk/pages/Geotrails.asp) and Geopark Shetland (http://www.geoparkshetland.org.uk/) [Accessed on 25 January, 2012].

${ }^{9}$ See http://iat-sia.com/index.php?page=scotland [Accessed on 25 January, 2012].

${ }^{10}$ See http://www.centralscotlandgreennetwork.org/ [Accessed on 25 January, 2012].

${ }^{11}$ See http://www.scotland.gov.uk/Resource/Doc/278232/0083591.pdf [Accessed on 25 January, 2012].

${ }^{12}$ At the time of writing (February 2012), the Scottish Geodiversity Forum is progressing the development of a Scottish Geodiversity Chanter that addresses these issues. See consultation document at http://scottishgeodiversityforum.org/charter/ [Accessed on 12 March, 2012].
}

\section{References}

Anderson, M.G. \& Ferree, C.E. (2010) Conserving the stage: climate change and the geophysical underpinnings of species diversity, PLOS ONE 5(7): e11554.doi:10.1371/journal.pone.0011554.

Australian Heritage Commission (2002) Australian Natural Heritage Charter for the Conservation of Places of Natural Heritage Significance (2nd edition) (Canberra: Australian Heritage Commission in association with the Australian Committee for the International Union for the Conservation of Nature).

Baxter, J.M., Boyd, I.L., Cox, M., Donald, A.E., Malcolm, S.J., Miles, H., Miller, B. \& Moffat, C.F. (Eds) (2011) Scotland's Marine Atlas: Information for the National Marine Plan (Edinburgh: Marine Scotland).

Beier, P. \& Brost, B. (2010) Use of land facets to plan for climate change: conserving the arenas, not the actors, Conservation Biology, 24, pp. 701-710.

Bide, T., Idoine, N.E., Brown, T.J. \& Smith, K. (2011) United Kingdom Minerals Yearbook 2010, British Geological Survey Open Report, OR/11/032.

Bradwell, T., Stoker, M.S., Golledge, N.R., Wilson, C.K., Merritt, J.W., Long, D., Everest, J.D., Hestvik, O.B., Stevenson, A.G., Hubbard, A.L., Finlayson, A.G. \& Mathers, H.E. (2008) The northern sector of the last British Ice Sheet: maximum extent and demise, Earth-Science Reviews, 88, pp. 207-226. 
British Geological Survey (2004) Exploring the Landscape of Assynt. A Walkers' Guide and Map Showing the Rocks and Landscape of Assynt and Inverpolly. Map at 1:50 000 scale (Keyworth, Nottingham: British Geological Survey).

British Geological Survey (2008) Minerals and you. Available at: http://www.bgs.ac.uk/mineralsuk/mineralsyou/home.html [Accessed on 25 January 2012].

Brooks, A.J., Roberts, H., Kenyon, N.H. \& Houghton, A.J. (2009) Assessing and developing the required biophysical datasets and datalayers for Marine Protected Areas network planning and wider marine spatial planning purposes. Report No.8 task 2A. Mapping of geological and geomorphological features. Unpublished report to Defra by ABPmer for Project MB102. Available at:

http://randd.defra.gov.uk/Default.aspx?Menu=Menu\&Module=More\&Location=None \&Completed=0\&ProjectID=16368 [Accessed on 25 January, 2012].

Brooks, A.J., Kenyon, N.H., Leslie, A., Long, D., Gordon, J.E. (2011) Characterising Scotland's marine environment to define search locations for new Marine Protected Areas. Part 2: The identification of key geodiversity areas in Scottish Waters, Scottish Natural Heritage Commissioned Report, No. 430.

Burek, C.V. \& Prosser, C.D. (2008) The history of geoconservation: an introduction, in: C.V. Burek \& C.D. Prosser (Eds) The History of Geoconservation (London: Geological Society, Special Publications, 300), pp. 1-5.

Committee of Ministers of the Council of Europe (2004) Recommendation Rec(2004)3 on conservation of the geological heritage and areas of special geological interest. Available at: https://wcd.coe.int/ViewDoc.jsp?id=740629\&Lang=en [Accessed on 25 January, 2012].

Corenblit, D., Tabacchi, E., Steiger, J. \& Gurnell, A.M. (2007) Reciprocal interactions and adjustments between fluvial landforms and vegetation dynamics in river corridors: a review of complementary approaches, Earth Science Reviews, 84, pp. 56-86.

Dearing, J.A., Braimoh, A.K., Reenberg, A., Turner, B.L. \& van der Leeuw, S. (2010) Complex land systems: the need for long time perspectives to assess their future, Ecology and Society, 15(4):21. [online] URL: http://www.ecologyandsociety.org/vol15/iss4/art21/ [Accessed on 25 January, 2011].

Department for Energy, and Climate Change (2012) Electricity Statistics. Available at: http://www.decc.gov.uk/en/content/cms/statistics/energy_stats/source/electricity/electri city

Defra (2010) Charting Progress 2. The State of UK Seas (Defra: London). Available at http://chartingprogress.defra.gov.uk [Accessed on 25 January, 2012].

Department for Communities and Local Government (2011) Annual Minerals Raised Inquiry Survey 2009. Available at:

http://www.communities.gov.uk/planningandbuilding/planningbuilding/planningresearc h/researchreports/mineralswasteresearch/annualmineralsraised/ [Accessed on 25 January, 2012].

Dowling, R.K. \& Newsome, D. (2010) Global Geotourism Perspectives (Oxford: Goodfellow Publishers).

Eder, W. \& Patzak, M. (2004) Geoparks - geological attractions: a tool for public education, recreation and sustainable economic development, Episodes, 27, pp. 162-164. 
Ellis, N. (2011) The Geological Conservation Review (GCR) in Great Britain - rationale and methods, Proceedings of the Geologists’ Association, 122, pp. 353-362.

European Commission (2011) Our life insurance, our natural capital: an EU biodiversity strategy to 2020, COM(2011) 244 final. Available at: http://ec.europa.eu/environment/nature/biodiversity/comm2006/2020.htm [Accessed on 25 January, 2012].

European Manifesto on Earth Heritage and Geodiversity (2004) Available at: http://www.eurogeologists.de/images/content/panels_of_experts/soil_protection_geolog ical_heritage/ManifestoEarthHeritage_Geodiversity.pdf [Accessed on 25 January, 2012].

Everard, M., Jones, L. \& Watts, B. (2010) Have we neglected the societal importance of sand dunes? An ecosystem services perspective, Aquatic Conservation: Marine and Freshwater Ecosystems, 20, pp. 476-487.

Gordon, J.E. (2010) The geological foundations and landscape evolution of Scotland, Scottish Geographical Journal, 126, pp. 41-62.

Gordon, J.E. (2012) Rediscovering a sense of wonder: geoheritage, geotourism and cultural landscape experiences, Geoheritage, 4, pp. 65-77.

Gordon, J.E. (in press) Engaging with geodiversity: 'stone voices', creativity and ecosystem cultural services in Scotland, Scottish Geographical Journal

Gordon, J.E. \& Barron, H.F (2011) Scotland's geodiversity: development of the basis for a national framework, Scottish Natural Heritage Commissioned Report, No. 417.

Gordon, J.E. \& Leys, K.F. (Eds.) (2001) Earth Science and the Natural Heritage. Interactions and Integrated Management (Edinburgh: The Stationery Office).

Gordon, J.E., Thompson, D.B.A., Haynes, V.M., MacDonald, R. \& Brazier, V. (1998) Environmental sensitivity and conservation management in the Cairngorm Mountains, Scotland, Ambio, 27, pp. 35- 344.

Gordon, J.E., Barron, H.F., Hansom, J.D. \& Thomas, M.F. (2012) Engaging with geodiversity - Why it matters, Proceedings of the Geologists' Association, 123, pp. 1-6.

Gray, M. (2004) Geodiversity: Valuing and Conserving Abiotic Nature (Chichester: Wiley \& Sons).

Gray, M. (2011) Other nature: geodiversity and geosystem services, Environmental Conservation, 38, pp. 271-274.

Gray, M. (in press) Valuing geodiversity in an “ecosystem services” context, Scottish Geographical Journal, xxx-xxx.

Gray, M., Gordon, J.E. \& Brown, E.J. (submitted) Enhancing the contribution of geodiversity in delivering ecosystem services, Proceedings of the Geologists’ Association,

Hambrey Consulting (2007) Social, economic and environmental benefits of World Heritage Sites, Biosphere Reserves, and Geoparks, Scottish Natural Heritage Commissioned Report, No. 248.

Hannis, S. \& Bee, E. (2008) Guide to mineral information in the Central Belt of Scotland, British Geological Survey Open Report OR/08/011. 
Holloway, J. \& Errington, L. (1978) The Discovery of Scotland. The Appreciation of Scottish Scenery Through Two Centuries of Scottish Painting (Edinburgh: National Gallery of Scotland).

Hopkins, J.J., Allison, H.M., Walmsley, C.A., Gaywood, M. \& Thurgate, G. (2007) Conserving Biodiversity in a Changing Climate: Guidance on Building Capacity to Adapt (London: Defra).

Hose, T.A. (2010) Volcanic geotourism in West Coast Scotland, in: P. Erfurt-Cooper \& M. Cooper (Eds) Volcano and Geothermal Tourism: Sustainable Geo-resources for Leisure and Recreation (London: Earthscan), pp. 259-271.

Hyslop, E.K., McMillan, A.A. \& Maxwell, I. (2006) Stone in Scotland (Paris: UNESCO).

IUCN (2008) Resolutions and Recommendations adopted at the 4th IUCN World

Conservation Congress. Resolution 4 040: Conservation of geodiversity and geological heritage. Available at:

http://intranet.iucn.org/webfiles/doc/IUCNPolicy/Resolutions/2008_WCC_4/English/R ES/res_4_040_conservation_of_geodiversity_and_geological_heritage.pdf [Accessed on 25 January, 2012].

Johansson, C.E. (Ed.) (2000) Geodiversitet I Nordisk Naturvård (Copenhagen: Nordic Council of Ministers).

Jones, L., Angus, S., Cooper, A., Doody, P., Everard, M., Garbutt, A. Gilchrist, P., Hansom, J., Nicholls, R., Pye, K., Ravenscroft, N., Rees, S., Rhind, P. \& Whitehouse, A. (2011) Coastal margins, in: The UK National Ecosystem Assessment Technical Report (Cambridge: UNEP-WCMC), pp. 411-457.

Lane, S.N., Odoni, N., Landström, C., Whatmore, S.J., Ward, N. \& Bradley, S. 2011. Doing flood risk science differently: an experiment in radical scientific method, Transactions of the Institute of British Geographers, 36, pp. 15-36.

Lees, R.G., Gordon, J.E. \& McKirdy, A.P. (1998) Coastal erosion, coastal defences and the Earth heritage in Scotland, in: J. Hooke (Ed.) Coastal Defence and Earth Science Conservation (London: The Geological Society), pp. 133-150.

Mace, G.M., Bateman, I., Albon, S., Balmford, A., Brown, C., Church, A., Haines-Young, R., Pretty, J.N., Turner, K., Vira, B. \& Winn, J. (2011) Conceptual framework and methodology, in: The UK National Ecosystem Assessment Technical Report (Cambridge: UNEP-WCMC), pp. 11-25.

McIntyre, D.B. \& McKirdy, A.P. (2012) James Hutton. The Founder of Modern Geology (Edinburgh: NMS Enterprises Limited - Publishing).

McKeever, P.J. \& Gallagher, E. (2001) Landscapes from Stone, in: J.E. Gordon \& K.F. Leys (Eds) Earth Science and the Natural Heritage. Interactions and Integrated Management (Edinburgh: The Stationery Office), pp. 262-270.

McKeever, P.J., Larwood, J. \& McKirdy, A.P. (2006) Geotourism in Ireland and Britain, in: R.K. Dowling \& D. Newsome (Eds) Geotourism: Sustainability, Impacts and Management (Amsterdam: Elsevier), pp. 180-198.

McKirdy, A.P. (2002) Environmental geology, in: N.H. Trewin (Ed.) Geology of Scotland (London: The Geological Society), pp. 473-483.

McKirdy, A.P., Threadgould, R. \& Finlay, J. (2001) Geotourism: an emerging rural development opportunity, in: J.E. Gordon \& K.F. Leys (Eds) Earth Science and the 
Natural Heritage. Interactions and Integrated Management (Edinburgh: The Stationery Office), pp. 255-261.

Millennium Ecosystem Assessment (2005) Ecosystems and Human Well-being: Current State and Trends, Volume 1 (Washington DC: Island Press).

Morrison, A. \& MacPhail, I. (2009) Landscapes \& People: Earth Heritage, Culture \& Economy. Conference Report, 7th European Geoparks Network Conference, 13 - 16 September 2007, Ullapool, Scotland, UK (Lochinver: North West Highlands Geopark) Available at: http://www.northwest-highlandsgeopark.org.uk/downloads/conferencereport2007.pdf [Accessed on 25 January, 2012].

Natural Capital (2011) Strategic assessment of the value and state of Scotland's geodiversity: links with the current policy framework, Scottish Natural Heritage Commissioned Report, No. 416.

Newsome, D. \& Dowling, R.K. (2010) Geotourism: the Tourism of Geology and Landscape (Oxford: Goodfellow Publishers).

Orr, H.G., Wilby, R.L., McKenzie Hedger, M. \& Brown, I. (2008) Climate change in the uplands: a UK perspective on safeguarding regulatory ecosystem services, Climate Research, 37, pp. 77-98.

Pethick, J. (1999) Future sea-level changes in Scotland: options for coastal management, in: J.M. Baxter, K. Duncan, S.M. Atkins \& R.G. Lees (Eds) Scotland's Living Coastline (London: The Stationery Office), pp. 45-62.

Pressey, R.L., Cabeza, M., Watts, M.E., Cowling, R.M. \& Wilson, K.A. (2007) Conservation planning in a changing world, Trends in Ecology and Evolution, 22, pp. 583-592.

Prosser, C., Murphy, M. \& Larwood, J. (2006) Geological Conservation: a Guide to Good Practice (English Nature: Peterborough).

Prosser, C.D., Burek, C.V., Evans, D.H., Gordon, J.E., Kirkbride, V., Rennie, A.F. \& Walmsley, C.A. (2010) Conserving geodiversity sites in a changing climate: management challenges and responses, Geoheritage, 2, pp. 123-136.

Prosser, C.D., Bridgland, D.R., Brown, E.J. \& Larwood, J.G. (2011) Geoconservation for science and society: challenges and opportunities, Proceedings of the Geologists' Association, 122, pp. 337-342.

Pye, M. \& Brown, S. (2002) Hydrocarbons, in: N.H. Trewin (Ed.) The Geology of Scotland (London: The Geological Society), pp. 461-471.

Rennie, A.F. \& Hansom, J.D. (2011) Sea level trend reversals: land uplift outpaced by sea level rise on Scotland's coast, Geomorphology, 125, pp. 193-202.

Rippon, J.H. (2002) Coal, in: N.H. Trewin (Ed.) The Geology of Scotland (London: The Geological Society), pp. 449-455.

Robson, A., Cowx, I.G. \& Harvey, J.P. (2011) Impact of run-of-river hydro-schemes upon fish populations, SNIFFER Project WFD114 (Edinburgh: Scotland \& Northern Ireland Forum for Environmental Research).

RPA \& Cambridge Econometrics (2008) The economic impact of Scotland's natural environment, Scottish Natural Heritage Commissioned Report, No. 304.

Scottish Executive (2004) Scotland's Biodiversity: It's in Your Hands - A strategy for the conservation and enhancement of biodiversity in Scotland. Available at: 
http://www.scotland.gov.uk/Resource/Doc/25954/0014583.pdf [Accessed on 25 January, 2012].

Scottish Geodiversity Forum (2012) Scotland's Geodiversity Charter (Edinburgh: Scottish Geodiversity Forum). Available at: http://scottishgeodiversityforum.org/charter/ [Accessed on 22 June, 2012].

Scottish Government (2008a) Science for Scotland (Scottish Government: Edinburgh). Available at: http://www.scotland.gov.uk/Publications/2008/11/24143207/0 [Accessed on 25 January, 2012].

Scottish Government (2008b) Good Places, Better Health. A New Approach to Environment and Health in Scotland (Scottish Government: Edinburgh). Available at: http://www.scotland.gov.uk/Topics/Health/good-places-better-health [Accessed on 25 January, 2012].

Scottish Natural Heritage (2004) Trails Through Time (Battleby: Scottish Natural Heritage).

Scottish Natural Heritage (2009) Developing the Contribution of the Natural Heritage to a Healthier Scotland (Battleby: Scottish Natural Heritage).

SEPA (2010) Guidance for developers of run-of-river hydropower schemes (Stirling: SEPA).

Stace, H. \& Larwood, J. (2006) Natural Foundations: Geodiversity for People, Places and Nature (Peterborough: English Nature).

Stanley, M. (2004) Geodiversity - linking people, landscapes and their culture, in: M. Parkes (Ed.) Natural and Cultural Landscapes - the Geological Foundation (Dublin: Royal Irish Academy), pp. 45-52.

Stoker, M.S., Bradwell, T., Howe, J.A., Wilkinson, I.P. \& McIntyre, K. (2009) Lateglacial ice-cap dynamics in NW Scotland: evidence from the fjords of the Summer Isles region, Quaternary Science Reviews, 28, pp. 3161-3184.

Stinton, A. (2009) Walking for health using geology and landscape. Earth Heritage Trust News, 24, pp. 6-7.

Thompson, D.B.A., Gordon, J.E. \& Horsfield, D. (2001). Montane landscapes in Scotland: are these natural, artefacts or complex relics? in: J.E Gordon \& K.F. Leys (Eds) Earth Science and the Natural Heritage: Interactions and Integrated Management (Edinburgh: The Stationery Office), pp. 105-119.

Trewin, N.H. (Ed.) (2002) The Geology of Scotland (London: The Geological Society).

UK National Ecosystem Assessment (2011) The UK National Ecosystem Assessment: Synthesis of the Key Findings (Cambridge: UNEP-WCMC).

Vaughan, I., Diamond, M., Gurnell, A., Hall, K., Jenkins, A., Milner, N., Naylor, L., Sear, D., Woodward, G. \& Ormerod, S. (2009) Integrating ecology with hydromorphology: a priority for river science and management, Aquatic Conservation: Marine and Freshwater Ecosystems, 19, pp. 113-125.

VisitScotland \& Scottish Natural Heritage (2002) Tourism Attitudes Survey, 2001.Final Report. Available at: www.snh.org.uk/pdfs/strategy/rural/sr-tass.pdf [Accessed on 25 January, 2012].

Werritty, A. \& Brazier, V. (1991) The Geomorphology, Conservation and Management of the River Feshie SSSI, Unpublished Report for the Nature Conservancy Council (Peterborough: England). 
Geodiversity Conference Proceedings for Scottish Geographical Journal. Final revised text 22 June 2012

Werritty, A., Brazier, V., Gordon, J.E. \& McManus, J. (1994) The freshwater resources of Scotland: a geomorphological perspective, in: P.S. Maitland, P.J Boon \& D.S. McLusky (Eds) The Freshwaters of Scotland: a National Resource of International Significance (Chichester: John Wiley), pp. 65-88.

Wilson, P. (Ed.) (2005) Building with Scottish Stone (Edinburgh: Arcamedia). 
Table 1. Geodiversity and Scotland's Strategic Objectives

\begin{tabular}{|c|c|}
\hline $\begin{array}{l}\text { Strategic } \\
\text { Objective }^{1}\end{array}$ & Contribution of Geodiversity \\
\hline $\begin{array}{l}\text { Wealthier } \\
\text { Scotland }\end{array}$ & $\begin{array}{l}\text { Scotland's industrial development during recent centuries has been founded on its } \\
\text { geological resources. Today, these are fundamental to economic development as a } \\
\text { source of: } \\
\text { - soil and water resources; } \\
\text { - energy and minerals; } \\
\text { - contributions to tourism and the growing area of geotourism, including geoparks; } \\
\text { - construction materials for new building projects; } \\
\text { - materials for the restoration of the built heritage; } \\
\text { - collectable items (e.g. rocks, fossils, minerals, and semi-precious stones). }\end{array}$ \\
\hline $\begin{array}{l}\text { Safer \& } \\
\text { Stronger } \\
\text { Communities }\end{array}$ & $\begin{array}{l}\text { Geodiversity contributes to better quality of life and stronger local communities } \\
\text { through: } \\
\text { - supporting services (e.g. soil formation, water cycling); } \\
\text { • provisioning services (e.g. products such as fresh water and building materials); } \\
\text { - regulating services (e.g. natural flood management, erosion control, coastal protection } \\
\text { and water regulation, based on understanding and working with natural processes in } \\
\text { an integrated way through shoreline management and catchment management } \\
\text { planning); } \\
\text { - cultural services (e.g. providing recreation and aesthetic experiences); people also } \\
\text { value the 'sense of place' that is associated with recognised features of their } \\
\text { environment, such as natural rock formations and landscapes, and the perceived } \\
\text { 'feeling of security' and character created by those features. }\end{array}$ \\
\hline Smarter & $\begin{array}{l}\text { Geodiversity has educational values and provides opportunities to enhance learning } \\
\text { achievements: } \\
\text { - across the spectrum of schools (supporting the Curriculum for Excellence), colleges, } \\
\text { universities (underpinning world-class research into how the Earth works) and life- } \\
\text { long learning (helping everyone to explore and appreciate the world around them and } \\
\text { gain inspiration from it); } \\
\text { - through enhanced understanding of natural Earth surface processes such as erosion } \\
\text { and flooding, geological processes that formed the landscape, climate change from } \\
\text { geological records and the links between geological and cultural heritage, helping to } \\
\text { contextualise human existence. }\end{array}$ \\
\hline Greener & $\begin{array}{l}\text { Geodiversity contributes to: } \\
\text { - understanding the drivers and effects of environmental change (e.g. climate change, } \\
\text { sea-level rise and carbon dynamics in organic (peat) soils); } \\
\text { - planning for adaptive management in response to climate change and rising sea-level, } \\
\text { based on understanding and working with natural processes (e.g. through } \\
\text { development of river basin management plans and natural flood management } \\
\text { involving restoration of natural processes and an understanding of floodplain histories } \\
\text { from sedimentary records); } \\
\text { - delivering sustainable, healthy places and environments in which to live, visit and do } \\
\text { business; wise use of non-renewable geodiversity resources (e.g. minerals, soils, fossil } \\
\text { fuels) is fundamental to sustainable development; } \\
\text { - linking people, nature and landscape: geodiversity supports habitats, species and } \\
\text { environmental quality and contributes to cultural heritage, sense of place and rural } \\
\text { fabric; Geoparks and other tourism developments can help to sustain living and }\end{array}$ \\
\hline
\end{tabular}


Geodiversity Conference Proceedings for Scottish Geographical Journal. Final revised text 22 June 2012

\begin{tabular}{|l|l|}
\hline Healthier & vibrant communities. \\
\hline & The management of Local Geodiversity Sites contributes to: \\
& • improving environmental health through soil and water quality; \\
& improving the quality and 'liveability' of local environments and greenspace, and \\
- fostering pride in the distinctiveness of local natural heritage and the aesthetic value \\
\\
\\
of landscapes; \\
• fostering healthier lifestyles through the support of physical activity, such as \\
recreation and adventure sports, and through spiritual enrichment, aesthetic \\
experiences, mental inspiration and cognitive development.
\end{tabular}

${ }^{1}$ Source: http://scotland.gov.uk/About/scotPerforms/objectives [Accessed on 25 January, 2012] 
Table 2. The contributions of geodiversity and geoconservation to selected National Outcomes

\begin{tabular}{|c|c|}
\hline National Outcomes $^{1}$ & Contributions of geodiversity and geoconservation \\
\hline $\begin{array}{l}\text { We value and enjoy our built and natural } \\
\text { environment and protect it and enhance it } \\
\text { for future generations. }\end{array}$ & $\begin{array}{l}\text { - Vital contributions to ecosystem services are } \\
\text { safeguarded. } \\
\text { - Understanding of natural processes informs } \\
\text { adaptations to climate change. } \\
\text { - Links between geodiversity and biodiversity are } \\
\text { better understood. } \\
\text { - The geo-archives in Scotland's rocks and landforms } \\
\text { are protected for study and enjoyment. } \\
\text { - Non-renewable resources are used sustainably. }\end{array}$ \\
\hline $\begin{array}{l}\text { We realise our full economic potential } \\
\text { with more and better employment } \\
\text { opportunities for our people. }\end{array}$ & $\begin{array}{l}\text { - Economic benefits are delivered through tourism (e.g. } \\
\text { in geoparks). }\end{array}$ \\
\hline $\begin{array}{l}\text { We live in well-designed, sustainable } \\
\text { places where we are able to access the } \\
\text { amenities and services we need. }\end{array}$ & $\begin{array}{l}\text { - Vital contributions to ecosystem services are } \\
\text { safeguarded. } \\
\text { - Understanding of natural processes informs } \\
\text { adaptations to climate change. }\end{array}$ \\
\hline $\begin{array}{l}\text { We reduce the local and global } \\
\text { environmental impact of our consumption } \\
\text { and production. }\end{array}$ & - Non-renewable resources are used sustainably. \\
\hline We live longer, healthier lives. & $\begin{array}{l}\text { - Public health benefits from outdoor activities and use } \\
\text { of greenspace. }\end{array}$ \\
\hline $\begin{array}{l}\text { We are better educated, more skilled and } \\
\text { more successful, renowned for our } \\
\text { research and innovation. }\end{array}$ & $\begin{array}{l}\text { Educational benefits from resources for universities, } \\
\text { schools and lifelong learning and fundamental } \\
\text { geoscience research. }\end{array}$ \\
\hline $\begin{array}{l}\text { We take pride in a strong, fair and } \\
\text { inclusive national identity. }\end{array}$ & $\begin{array}{l}\text { - Geodiversity underpins the character of Scotland's } \\
\text { natural and built landscapes, which contributes to } \\
\text { national identity. }\end{array}$ \\
\hline
\end{tabular}

\footnotetext{
${ }^{1}$ Source: http://scotland.gov.uk/About/scotPerforms/outcomes [Accessed on 25 January, 2012]
} 